\title{
This Is a Man's World: Drag Kings and the Female Embodiment of Masculinity
}

\author{
Asunción Aragón Varo \\ University of Cadiz \\ asuncion.aragon@uca.es
}

\begin{abstract}
Portrayals of non-heteronormative characters have been more and more present in the mass media since the last decades of the 20th century. Gay and lesbian characters are now part of mainstream media in films, sitcoms, drama series, talk shows, etc. Apparently, this could mean that nonheteronormative identities and desires are tolerated by the general audience but this might be just so as long as these characters behave according to heteronormative standards of normality or their bodies are easily readable. The presence of trans, drags or genderqueer characters is minimal and with it the potential subversion of the heteronormative matrix. However, not all drag is subversive and therefore an inappropriate reading or decoding could end up reinforcing the same normative gender identities they intend to subvert. To understand the potential subversion of non-heteronormative characters this paper aims to analyze briefly the re/conceptualization of performativity in the work of Judith Butler, the representation of drag as a parody of gender performance, the female embodiment of masculinity and its representation in popular culture.
\end{abstract}

\section{Introduction}

Portrayals of non-heteronormative characters have been more and more present in the mass media since the last decades of the $20^{\text {th }}$ century. Gay and lesbian characters are now part of mainstream media in films, sitcoms, drama series, talk shows, etc. Their 
presence has become not just trendy or cool, but also a magnet for ever-growing audiences, a revenue generating business in the entertainment industry. Apparently, this could mean that non-heteronormative identities and desires are tolerated by the general audience, consider the popularity of mainstream television series such as Modern Family, The L-Word, Queer as Folk, but this might be just so as long as these characters behave according to heteronormative standards of normality or their bodies are easily readable. The presence of trans, drags or genderqueer characters is minimal and with it the potential subversion of the heteronormative matrix. However, not all drag is subversive and therefore an inappropriate reading or decoding could end up reinforcing the same normative gender identities they intend to subvert. To understand the potential subversion of non-heteronormative characters this paper aims to analyze briefly the re/conceptualization of performativity in the work of Judith Butler, the representation of drag as a parody of gender performance, the female embodiment of masculinity and its representation in popular culture.

\section{The performativity of gender}

Simone de Beauvoir's assertion "One is not born but becomes a woman" is probably one of the most famous and well-known lines in the history of feminist thinking. This idea introduced the sex-gender distinction which implied the biological nature of sex versus the cultural one of gender. In 1990 another feminist, Judith Butler, in Gender Trouble, now a milestone in feminist theory, delves into Beauvoir's statement. For Butler, we are born into a sexed body but become our gender in a process where "gender" is not a matter of being or having but of performing as "the stylized repetition of acts" (1988: 520) constituted in time. Thus Butler proposes a theory of the performativity of gender, and of the performative production of identity. Butler concedes that her theory of performativity not only has changed over time in response to criticisms, but also "waffles between understanding performativity as linguistic and casting it as theatrical" (1999: xxv). Throughout her works Butler distinguishes between performance and performativity, the latter being carried out through the repetition of norms which are not under the control of the performer's choice; moreover what is performed attempts to mask the performative, that is, to conceal what remains unconscious. Thus, according to Butler, performance "presumes a subject" and performativity "contests the very notion of a subject" (1994: 33). Therefore, this becoming a 'woman' or a 'man' is not founded on free will but on an imposed cultural performance. One becomes a 'man' or a 'woman' in conformity with and as result of normative ideals of gender. The trouble, to use Butler's term, arises with those 'radical' bodies, those genders that do not conform to heteronormative regulations, those who transcend and question the cultural binaries and discourses that determine what is a woman or a man, those persons whose body, gender and desire are at odds with this grid of gender intelligibility. 
Butler's theory of gender as a performative act was already present in her article "Performative Acts and Gender Constitution: An Essay in Phenomenology and Feminist Theory" (1988), where she analyses the phenomenological theory of acts and the way in which social reality is constituted through symbolic social signs (language, gesture, etc). If gender is instituted through a sequence of acts which are reified, naturalised and sedimented on a temporal basis, then the constituted gender identity is no more than the appearance of a substance, an illusion that actors themselves believe to be real since bodily gestures, enactments of several kinds produce the effects of a predetermined, fixed "natural" gender identity. Therefore, as Butler contends, "what is called gender identity is a performative accomplishment compelled by social sanction and taboo. In its very character as performative resides the possibility of contesting its reified status" (1988: 520). There is then a site of potential subversion in Butler's concept of performativity; as Lisa Disch comments, in Butler's work "the 'politics of the performative' is a politics of insurrection" (1999: 547).

In this article Judith Butler also introduces the idea of a more "theatrical" analysis of gender acts since she conceives that the phenomenological perspective of constructed acts is too limited by its individualistic assumptions. This theatrical character of gender acts also opens the path for Butler's notion that gender identity is based on a performance of gender that has been repeated historically and conventionally by previous actors. The gender script has been rehearsed by many different actors, it has already been on stage before the actors start their performance but its repetition has been nevertheless required for individual actors to convey a particular gender that has already been socially established. In this way Butler is not suggesting a theatrical model of performance to show the production of gender identities but, as Moya Lloyd states, to "explain the collective dimensions of performativity" (2007: 59, italics in the text).

The theory of a discursive constitution of gender is further expanded in Butler's Gender Trouble (1990) which from the very first chapter deals with the issue of performativity. Throughout her work Butler insists on differentiating 'performance' from 'performative' in her refusal of a pre-linguistic subject who performs the gender acts, since the subject is performatively constituted by them becoming therefore the effect of discourse not its cause. Gender identities are constituted by language, there is no subject "I" outside language; it is as the result of signifying practices that the "I" appears in a "regulated process of repetition that both conceals itself and enforces its rules precisely through the production of substantializing effects" (Butler, 1990: 145, italics in the text).

Butler's concept of performativity is linked to the speech act theory of J.L. Austin's How to Do Things with Words (1955) and Derrida's deconstruction of Austin's ideas in his essay "Signature Event Context" (1972). Butler takes from Austin the idea that language is performative, but in her book Bodies that Matter (1993) she reformulates her concept of performativity taking into account the Derridean emphasis on citation to contend that 'performativity must be understood not as a singular or deliberate 'act', but, rather, as the reiterative and citational practice by which discourse produces the effects that it names" (1993: 2). Thus, within this framework, the performative act of 
pronouncing "it's a boy" or "it's a girl" at birth initiates the chain of citations that constitute the "girling" of a girl, the force of this performative utterance lies on its compelling the "girl" to cite and repeat the gendered norms for qualifying as a viable and intelligible subject. Therefore, as Butler contends, "[f]emininity is thus not the product of a choice, but the forcible citation of a norm, one whose complex historicity is indissociable from relations of discipline, regulation, punishment" (1993: 232).

This view of performativity implies that we are linguistically constituted but not necessarily determined by language since, although speech acts must be forcibly repeated to be effective, this repetition is not just mechanical and therefore there would be the possibility of recitation in undeliberate ways - that is, the possibility of subversion or agency in our recitation or performance of masculinity and femininity. As Gill Jagger comments regarding Butler's Excitable Speech (1997), there is always an ambivalent structure in Butler's concept of performativity: "Speech acts do not simply reflect social power, established social conditions or official discourse but, rather, always involve the possibility of subversive resignification" (2008: 125).

Thus the performative production of gender identities also provides mechanisms for its subversion. For Butler a case in point is the use of parody and drag to reveal the imitative structure of gender and its subversive potential to denaturalize heteronormativity: "[...] drag fully subverts the distinction between inner and outer psychic space and effectively mocks both the expressive model of gender and the notion of a true gender identity" (1990: 137).

\section{Drag and the parodic performance of gender}

Butler uses the concept of drag near the end of Gender Trouble (1990) to highlight the imitative character of gender. According to Butler, drag performances reveal the dissonances between anatomical sex (male) and performance, anatomical sex (male) and gender (femininity), and gender (femininity) and performance. By creating a "unified picture of "woman" drag demonstrates the artificial naturalization of gender coherence. There is no inner truth of gender but a fantasy "instituted and inscribed on the surface of bodies" (1990: 136). As we noted above, to her, gender is a corporeal style, "the mundane way in which bodily gestures, movements, and styles of various kinds constitute the illusion of an abiding gendered self' (1990: 140); there is no 'I' preceding the performed gender since the repetition and the failure to repeat produce a chain of performances that simultaneously constitute and challenge the coherence of that 'I'; thus the performance of gender needs to be repeated, to be imitated, and the 'I' is a fantasy. Therefore there are neither true nor false genders; all genders are regulatory fictions, illusions produced performatively.

The parodic performance of drag reveals the derivative structure of gender inasmuch as it questions the opposition between 'true' and 'false' genders, between 'original' and 'copied' gender identities that take for granted the assumption of heterosexuality - gender identity being the primary and 'original', and non- 
heteronormative sexualities the copy, the shadows of the 'true' and 'original' one. As Butler contends "gay is to straight not as copy is to original, but, rather, as copy is to copy. The parodic repetition of 'the original' [...] reveals the original to be nothing other than a parody of the idea of the natural and the original" (1990: 31 ). Heterosexuality is, thus, turned into a comedy, a parody of itself.

Butler's analysis of drag is based on her own reading of the anthropological studies of drag artists carried out by Esther Newton in Mother Camp: Female Impersonators in America (1972). According to Newton drag is not a copy of some primary or true gender since drag enacts the very structure of impersonation by which any gender is assumed; all gender identities imply some sort of impersonation. In this way impersonation turns out to be one of the mechanisms in the production of gender identities, since "gender is a kind of persistent impersonation that passes as the real" (1990: viii). Butler takes from this idea of impersonation the hint that drag is thus not a question of appropriating or expropriating the gender that "rightly" belongs to any group which takes for granted that gender is sex's cultural property and that 'masculinity' belongs to 'male' and 'femininity' belongs to 'female'.

The idea of an original gender identity is thematized in the parodic cultural practices of drag. If, as Butler emphasizes, there is no inner truth of gender, it follows that there is no primary and original gender identity for drag to imitate; that is, if we accept that gender is performatively produced there is no possibility of an original gender but a repetition of a repetition that produces the effect of being taken as original, engendering in this way a phantasmatic idea of 'woman' or 'man'. According to Butler (1990: 140) these are phantasmatic identifications because gender norms are impossible to embody. "All gender enactment comprises a failure to become 'real' and to embody 'the natural"' (Lloyd, 1999: 198). If there is always a compulsion to repeat, this repetition will never fully accomplish the ideal of gender identity and hence its phantasmatic structure, and paradoxically its openness to resignification and subversion. Thus, as we noted, if heterosexuality is an imitation performatively constituted as original, Butler contends that the parodic imitation of heterosexuality performed by drag artists is just an imitation of an imitation for which there is not any original, hence "[in] imitating gender, drag implicitly reveals the imitative structure of gender itself as well as its contingency" (1990: 137, italics in the text). As a consequence drag sabotages the assumption that heterosexuality is the original primary gender identity and non-heterosexual gender identities a fake, a failed copy of the original. Butler is also questioning the idea that in butch/femme relations there is an appropriation of heterosexual norms. As Gill Jagger comments, "against the view in some feminist theories that drag acts and some aspects of gay and lesbian relationships, such as butch/femme, imitate stereotypical heterosexual relations, Butler argues that they rather demonstrate that the very idea of an original heterosexuality is a myth" (2008: 32).

Drag acts denaturalize through parody the notion of a "core", "inner", pre-given gender identity and with it the assumption that heterosexuality lies at the heart of it. But does it mean that all drag is subversive per se? Certainly not. 
There have been some misreading of Butler's theory of gender performativity and drag. These 'bad', or at least controversial, readings, particularly of Gender Trouble, presuppose the existence of a voluntarist, humanist subject, an instrumental and wilful subject who decides or chooses his/her own gender freely, someone who wears gender as drag. However, Butler criticizes this interpretation of her concept of gender as performative since, as she explains in Bodies that Matter, it would mean that she believes that "one woke in the morning, perused the closet or some more open space for the gender of choice, donned that gender for the day, and then restored the garment to its place at night" (1993: x); on the contrary, she contends "I never did think that gender was like clothes, or that clothes make the woman" (1993: 231).

Drag is definitively an example but not the paradigm of performativity or subversion, since as Butler contends in Bodies that Matter (1993) and in the preface to her 1999 anniversary edition of Gender Trouble not all drag, not all parody is necessarily subversive. As she had already written about this in 1990: "Parody by itself is not subversive, and there must be a way to understand what makes certain kinds of parodic repetitions effectively disruptive, truly troubling, and which repetitions become domesticated and recirculated as instruments of cultural hegemony" (139). Thus, a proliferation of drag performances does not guarantee their success in questioning gender norms. Neither does subversion result automatically nor can its effects be foreseen or anticipated. There are incalculable effects in subversive actions, in performative acts; Butler cites several subversive activities in the histories of queer people such as cross-dressing, drag balls, street walking, butch-femme spectacles, dieins by ACT UP, kiss-ins by Queer Nation, drag performance benefits for AIDS. These activities challenged gender norms by disrupting the "closeting distinction between public and private space" and becoming sites of "politicization and AIDS awareness throughout the public realm" (1993: 233). In the case of drag, Chambers and Carver read Butler's theory of drag performance as centrally concerned with its subversive potential to expose the internal structure of heteronormative. Since heteronormativity makes sexuality legible, one simple way to subvert it is by "challenging, calling into question and/or undermining the presumption of heterosexuality" (2008: 155, italics in the text). Thus, according to Chambers and Carver (2008: 155-156), the subversion of heteronormativity can take place in many different ways; they give as examples projects that deconstruct heterosexuality by demonstrating its discursive effects and internal contradictions. They also think of new conceptualizations of sex/gender/desire that interrupt the heterosexual matrix, those disputing the heteronormative presumptions of earlier theorists or devising new workings of desire. These subversive acts are not limited to theory; the questioning of heteronormativity can be carried out in our daily lives in many different ways: by using a more inclusive language, for instance the use of more gender-neutral terms such as "partner"; by removing the signs from the bathroom/lavatory doors, or by challenging the notion that marriage is inherently heterosexual; a case in point is the critique of the Federal Defense of Marriage Act (DOMA). The DOMA, specifically Section Three, prevents the federal government from recognizing any marriages between gay or lesbian couples for the purpose of 
federal laws or programs, even if those couples are considered legally married by their home state. This act is being currently challenged in court since it is argued that it violates the constitution's "equal protection" promise. Whether legal or illegal the DOMA as such presupposes the notion that any marriage is heterosexual per se. As Chambers and Carver point out plainly

[...] legislators across the US have made it clear that they see themselves as responding to an imminent threat. This threat is certainly not, as those legislators would have it, against the 'sacred institution of marriage', but it may well be a threat to heteronormativity, to the easy presumption of heterosexuality. (2008: 156)

Regardless of the outcome of this process and the different strategies used to undermine the power of heteronormativity, it is relevant to stress that any collective or individual subversion, as we will comment concerning drag kings, must be conceived as internal, that is socially, culturally, historically and politically contextualized. As Butler contends: "If subversion is possible, it will be a subversion from within the terms of the law, through the possibilities that emerge when the law turns against itself and spawns unexpected permutations of itself" (1990: 93, my italics).

\section{The female embodiment of masculinity}

In this context, the notion of female masculinity - referred to diversely queer subject positions such as drag king, butch, female-to-male [FTM] transmen, operative and nonoperative, trans-gendered man, stone butch - deals with many of these questions since they confront the heteronormative ideal of an embodied gender, sexuality, female sexuality and identity.

The female embodiment of masculinity or drag king performances can also become a site of potential resistance and subversion of heteronormativity within the binary gender system.

Drag king performances became popular in many queer clubs in the United States in the mid 1990s, though there had been many performances before 1995 such as the Women's Drag competition in Buffalo, New York in 1992 and San Francisco's Drag King Contest 1994 (Maltz, 1998: 285). Drag king contests became so popular that in 1995 a calendar was published with some of the best contestants.

The performances of current drag kings are also different from the earlier performances of cross-dressing female entertainers, such as Gladys Bentley in the 1920s Harlem Renaissance, Marlene Dietrich in the 1930s, or Storme DeLaverie in the 1950s and 60s; while drag kinging is a recent phenomenon, female impersonators or cross-dressers have been a theatrical performance at least since the nineteenth century. Judith Halberstam in her groundbreaking book Female Masculinities (1998) explains the differences between drag kings and male impersonators in that "[w]hereas the male impersonator attempts to produce a plausible performance of maleness as the whole of her act, the drag king performs masculinity (often parodically) and makes the exposure 
of the theatricality of masculinity into the mainstay of her act" (1998: 232). Halberstam also distinguishes a drag butch from drag kings and male impersonators since the former, "a masculine woman who wears male attire as part of her quotidian gender expression" (1998: 232), is a lesbian role and the latter are not necessarily so.

The term 'female masculinity' challenges the notion that masculinity is nonperformative or anti-performative, as it is often presented, dislodging the 'masculine body' from 'masculinity' or embodying it with 'femininity'. Following Butler's theory of gender performativity we could contend that the best place to find what masculinity is, lies not in men but in the performative structure of masculinity, in its parodic performance, or in what is not deemed as 'masculine enough' - that is, a nonhegemonic, white, middle class, heterosexual masculinity. Drag kings' parody of masculinity subverts this notion that there is a 'real' masculine gender, a 'natural' masculinity that 'just is' in contrast to the artificiality, transferability associated with the feminine or with the masquerade of femininity. Therefore, as we commented above, if we follow Butler's contention that "gay is to straight not as copy is to original, but, rather, as copy is to copy" (1990: 31), then drag kings" parodies not only denaturalize the idea of an essential masculinity, they also expose its imitative structure, hence drag king performances are not a copy of masculinity but a copy of a copy of masculinity. Thus male masculinity is also performative; it can be performed not just by male bodies but also by female ones, undermining in this way the notion that masculinity is inevitably and naturally inherent to men. As Halberstam argues "masculinity does not belong to men, has not been produced only by men, and does not properly express male heterosexuality. [...] [W] hat we called 'masculinity' has also been produced by masculine women, gender deviants, and often lesbians" (1998: 241).

Halberstam (1998: 246-253) also tries to delineate between different types of drag performance in the drag king contests: "Butch Realness", "Femme Pretender", "Male Mimicry", "Fag Drag" and "Denaturalized Masculinity."

In the 'Butch Realness' category we usually have a drag king, a butch who could easily pass off as male, convincing of her masculinity in a fascinatingly unadorned performance. Within this category masculinity is reshaped into an alternative one which interestingly tries to be 'disidentified' with other forms of hegemonic masculinities. The 'Femme Pretender' category is obviously at the other extreme of 'Butch Realness'. These performers act like drag queens in their ironical and campy performance of masculinity but their performances, as Halberstam notes, offer "a consolidation of femininity rather than a disruption of dominant masculinity" (1998: 250). In the "Male Mimicry' performance, the drag kings pose a clearly form of male masculinity and try to perform it with subtle or overt irony. In the 'Fag Drag' category drag kings imitate the 'Castro clone' gay masculine aesthetic associated to urban gay ghettos, an aesthetic that "depends on leather and denim and a queer biker look" (1998: 253). Finally in Halberstam's taxonomy of female masculinities we find the 'Denaturalized Masculinity', the most interesting of drag king performances since it plays brightly and wittily within the categories of 'Femme Pretender' and 'Male Mimicry'. Drag kings in 
this category perform an alternative mode of masculinity while maintaining an ironical theatrical performance.

This typology has been criticised for its limitation to the drag king scenes in New York, London, and San Francisco; in fact it belongs to the earliest and most popular drag kings of the late 90s. Nowadays younger drag king performers work in the coastal cities and the U.S. Midwest, in cities such as Columbus, where the first International Drag King Community Extravaganza (IDKE) took place in 1999, or Cleveland where the 2012 edition has been hosted. All these drag king shows, nevertheless, share their potential to subvert, revise and parody male masculinities.

It is also noticeable that many of the present day research on drag kinging is autobiographical, produced by actual performers who focus on their own experience, particularly as members of a troupe. This writing explores the effects of drag king performances on its audience but also on the performers themselves; therefore it allows for a more comprehensive analysis of drag kinging.

Eve Shapiro (2007) focused her case study on the feminist drag troupe the Disposable Boy Toys (DBT), based in Santa Barbara; this is an autoethnographical research since Shapiro was an active member of DBT throughout the study. Shapiro's aim is to show that drag is not just a subversive practice in gender politics, but also an embodied experience in our daily life since "the process of participating in drag communities may also function as a form of consciousness raising and a site of identity transformation for performers" (2007: 251). One of the results of this research is that gender identity shifts in most of the troupe members who either reconceptualise their own gender identity or come to a new one calling themselves genderqueer, female to male (FTM), and transgender. This shift originated because of the opportunity it provided to imagine and question different gender identities, "a range of gender identities that overlap and move in and out of salience" (2007: 261), on their daily performances.

Another interesting feature of the Disposable Boy Toys is that the troupe was a selflabelled "political feminist collective" with a distinctive "feminist mission" (255). Their feminist ideology also worked to deconstruct gender misconceptions and prejudices among its members, drawing the troupe into understanding that gender is performatively constructed or that gender transgression is a political act; therefore as a feminist political act, Shapiro narrates, some members chose to perform femininity instead of any other gender identity since they deemed that their enactment would be a resisting practice in queer and heterosexual communities that privilege masculinity; in this way they considered that "continuing to call themselves 'women' was a political act" (Rupp et al., 2010: 284). The Disposable Boy Toys performed on stage for four years and were involved in queer theory and activism all the time. As Shapiro contends they "viewed performing girl drag as one way to claim space for and empower femininity" (2007: 264).

Recent research on drag king performances also deals with the distinct embodied effects of female masculinity on those women who practice it; the effects are manifold, 
as Julie Hanson notes, they felt "powerful, positive, affirming, erotic and sexual" (2007: 63).

Thus performing masculinity becomes a multicorporeal embodied act, a female corporeal mode of being masculine which empowers its female practitioners. Drag kings remark the thrilling awareness of subverting gender roles or identities and trespassing the gender norms ascribed to a female body; for many drag kings their performances allow them to question themselves and the boundaries of femaleness, contesting in this way the heteronormativity of the binary gender system. According to Hanson "drag king embodiment could be seen as an embodied form of subversion and liberation founded on the paradox of complicity to and rebellion against traditional conventions and discourses surrounding the female body, subjectivity and embodiment" (2007: 70).

\section{Screening drag kinging}

Although many scholarly studies and articles have been published on male femininity or drag queens, not much work has been done on the drag king phenomenon. In the American entertainment industry they hardly appear on mainstream TV shows, popular series or films. If invited to take part on a talk show drag kings either have little opportunity to talk about their performances or to express about the complexities of their gender identities. Most drag kings are invited to TV talk shows or news just to shock and amuse the audience with their "playful" indeterminacy. Unfortunately, as Halberstam regrets, "[o]n every occasion that drag kings appeared on 'straight' TV, they were deployed as an entertaining backdrop against which heterosexual desire was showcased and celebrated" (2003: 316). There is then a more voyeuristic interest in drag kings than a questioning of the binary of gender they potentially subvert. Drag king, female masculinity characters are present in Showtime's series The L Word (20042009), the first series that focuses mainly on a group of lesbians, though there are also straight and bisexual women, who live in a friendly and upper-middle-class neighbourhood of Los Angeles. At the end of its first season, in episode 12, "Locked up", the Planet Cafe is running a drag king show, "Kings of the Night." On the stage a drag king in a cowboy outfit is lip-syncing to music "I am a man, baby, that's what I am", and then he rips open his shirt, exposing a tight t-shirt underneath at which all the audience gets mad. After this drag king, Phil McCockin, leaves the stage, the owner of the cafe, Kit, introduces the character of Ivan Aycock. He is dressed as Willy DeVille, lead singer of Mink DeVille; he wears a black velvet suit, boots, a pencil-thin moustache and an elaborate black pompadour in a parody of 1970 s masculinity. Ivan stars lip syncing to "Savoir Faire": "I was standing on the corner of the avenue / I was watching all the girls go by [...] / And there she was in a five and ten cent store / Somehow I got to make her mine / Somehow I got to make her mine." Ivan's gender identification is undecidable. He starts courting Kit, a straight character, who becomes more and more attracted to him. Her feelings confuse her not because she thinks she is 
changing her sexual orientation but because Kit feels attracted to Ivan, to his female masculinity. In the next episode "Limb from Limb", in a dialogue between Kit and her sister Bette, each one names Ivan using the pronoun he or she. For Kit Ivan is definitely 'he':

BETTE: She's madly in love with you, you know.

KIT: No, he's not, we're friends. He helps me out with stuff.

BETTE: That's because she is in love with you and she wants to be your husband.

KIT: No, it's not like that.

BETTE: Kit, believe me. You may not be able to read the signals, but they're there. I saw the way she looks at you. She is fully courting you, old school, and you're letting her.

KIT: Is that so?

BETTE: Yeah, it is.

KIT: Well thank you for the lessons in the ritual mating habits of indigenous lesbians. Maybe next week we'll do butch and femme role-playing.

Kit's heterosexuality is questioned by this troubling desire. During the episode she tells Ivan that if he were a man he would be the perfect one and later on Ivan performs a drag act privately for her singing Leonard Cohen's "I'm your man." He sings, "if you want a lover, I'll do anything you ask me to / If you want another kind of love,

I'll wear a mask for you. [...] / If you want a partner, take my hand. [...] / Here I stand, I'm your man." Ivan is definitely working very hard to get Kit's approval, to be her man, even if it means wearing a mask, the masquerade of "manliness." Interestingly Ivan is more than just a man, he is also a butch, a she-he, he-she, and as he says is "happy either way", the character trespasses the limits between gender and anatomy, desire and sexual practice or identity and performativity; this fluidity contains, as we have commented, the potential to subvert the notion of heteronormativity.

After all, what is a 'man'? The parodic performances of drag kings reveal that there no 'real', original or natural masculinity and that it is possible to conceptualize masculinities without men (Halberstam, 1998). The documentary Venus Boyz (2002), by Gabriel Baur, portrays many examples of the female embodiment of masculinity. The director presents her work as a long journey in search of women who "live in between, who also live the man within, whatever that means." The documentary starts at a drag king night in a club in New York and goes on inquiring into the everyday lives of these drag kings who perform masculinity "some for a night, others for their whole lives" (www.venusboyz.com). The film starts with a woman in front of a mirror applying wrong facial hair on a beard about to start her performance, her masquerade of 'manliness'. One of the protagonists of Venus Boyz is the activist and artist Diane Torr, who talks about her workshops "Man for a Day", which she has been teaching for more than twenty years. In 1992 Torr - as Danny King - started her drag king workshops where participants from all ages, genders, sexualities and nationalities learn about the gestures, the motion, the physical presentation involved in performing different masculinities. They are taught how to make cotton-wool penises, apply facial hair, bind their breasts and go out to pubs, restaurants or gay clubs performing masculinity with a 
twist . As we commented above, Torr and other drag kings agree on the power and security they felt when performing masculinity on and off stage: "People step aside when I walk down the street, you always get a seat in the subway" or "you have a lot more credibility as a man: you walk into a room and everyone will pay attention" (Venus Boyz).

Mildred/Dred, a Haitian-American drag king, also finds kinging empowering: "[d]iscovering the man in me empowers the woman I really am"; she thinks that "everybody has a masculine and feminine side. But not everybody chooses to explore the other side" (Venus Boyz). In their parody, drag kings potentially subvert the assumed 'natural' connection between masculine bodies and power. This correlation is an illusion, as are the fake penis, facial hair or any other devices used in drag kinking since, if we agree with Butler's theories, all genders are ultimately illusions produced performatively. As Maureen Fisher (aka 'Mo B. Dick') comments "a drag king is a person who wants gender euphoria! A drag king is a person who has accepted his female masculinity!" (Venus Boyz).

Mil/Dred Gerestand does not identify herself as butch or femme: "I'm just whatever I'm feeling. I can be one way one day and one way another" (Venus Boyz); she cannot put herself into a category; she is a 'Wo-Man'. In her performances we can find this mixing up of genders, as Mil/Dred notes, "[a] lot of kings I know don't like to show their womanhood... but I like to mix it up" (Venus Boyz), so during the performance Dred reveals Mildred's breasts, then removes her "package" — an apple —and eats it. This notion of fluidity or ambiguity destabilizes assumptions about the masculine/feminine binary gender system and the association of power and masculinity. As Escudero Alías notes on Mil/Dred's performances, "[t]he gender hybridity found in her shows and costumes also queers the traditional sex/gender system to interesting effects: the audience is required to participate in the redefinition of gender and race premises of identity, thus collaborating and showing its complicity with the destabilization of power hierarchies" (2010: 171-172).

As a conclusion, we contend that female-embodied masculinities undermine the enactment of manliness and masculinity; from this perspective, we could also claim that drag king parodies potentially subvert the notion of a true, inner gender identity and expose the performative structure of gender. However, it is also essential to stress that even though drag kings' playful performances can be regarded as cool or fashionable, many gays, lesbians, transgender persons or gender queers face multiple terms of violence in their day-to-day interactions with society; they are punished for not doing their gender 'right'.

Off-stage transgressive performances are quite often dangerous, as Butler notices: "[...] the sight of a transvestite onstage can compel pleasure and applause while the sight of the same transvestite on the seat next to us on the bus can compel fear, rage, even violence" (1988: 527). In spite of the risk, drag kinging opens up new possible ways for destabilizing gender categories and blurring the boundary and borders of femininity and masculinity. Their female embodiment of masculinity has an impact on their audience, which would probably leave the show questioning their genders and 
desires; drag king performances may function as a form of consciousness-raising, a challenge to the audience and to the performers themselves to conceptualize the performative structure of gender and hence new ways of being, of experiencing genders and bodies that were categorized as freaks not so long ago.

\section{References}

Butler, Judith (1988): "Performative Acts and Gender Constitution: An Essay in Phenomenology and Feminist Theory." Theatre Journal 40(4): 519-531.

(1990): Gender Trouble: Feminism and the Subversion of Identity. New York: Taylor \& Francis Group.

- (1993): Bodies That Matter: On the Discursive Limits of Sex. New York: Routledge.

_ (1994): "Gender as Performance: An Interview with Judith Butler." Radical Philosophy 67(Summer): 32-39.

- (1999): Gender Trouble: Feminism and the Subversion of Identity, Anniversary Edition. New York: Routledge.

Chambers, Samuel E. and Terrell Carver (2008): Judith Butler and Political Theory: Troubling Politics. New York: Routledge.

Disch, Lisa (1999): "Judith Butler and the Politics of the Performative." Political Theory 27(4): 545-559.

Escudero Alías, Maite (2010): "Shattering Gender Taboos in Gabriel Baur's Venus Boyz." Journal of Gender Studies 19(2):167-179.

Halberstam, Judith (1998): Female Masculinity. Durham, NC: Duke University Press.

_ (2003) "What's That Smell? Queer Temporalities and Subcultural Lives." International Journal of Cultural Studies 6(3): 313-333.

Hanson, Julie (2007): "Drag Kinging: Embodied Acts and Acts of Embodiment." Body \& Society 13(1): 61-106.

Jagger, Gill (2008): Judith Butler. Sexual Politics, Social Change and the Power of the Performative. New York: Routledge.

Lloyd, Moya (1999): "Performativity, Parody, Politics.” Theory, Culture \& Society 16(2): 195213.

- (2007): Judith Butler: From Norms to Politics. Cambridge: Polity Press.

Maltz, Robin (1998): "Real Butch: The Performance/ Performativity of Male Impersonation, Drag Kings, Passing As Male, And Stone Butch Realness." Journal of Gender Studies 7(3): 273-286.

Rupp, Leila, Verta Taylor and Eve Ilana Shapiro (2010): "Drag Queens and Drag Kings: The Difference Gender Makes.” Sexualities 13(3): 275-294.

Shapiro, Eve Illana (2007): "Drag Kinging and the Transformation of Gender Identities." Gender \& Society 21(2): 250-71.

The L Word "Locked up." (Season 1, episode 12). Created by Ilene Chaiken. Dir. Lynne Stopkewich. Showtime. 2003.

The L Word "Limb from Limb." (Season 1, episode 13). Created by Ilene Chaiken. Dir. Tony Goldwyn. Showtime. 2003.

Venus Boyz, Dir. Gabriel Bauer. 2002. Onix Film Distribution.

Venus boyz's website. http://www.venusboyz.com (accessed 7 October 2013). 